\title{
Influence of hydraulic conductivity on communities of microorganisms and invertebrates in porous media A case study in drinking water slow sand filters
}

\author{
Journal Article \\ Author(s): \\ Mauclaire, Laurie; Schürmann, Andreas; Mermillod-Blondin, Florian \\ Publication date: \\ 2006-03 \\ Permanent link: \\ https://doi.org/10.3929/ethz-b-000037238 \\ Rights / license: \\ In Copyright - Non-Commercial Use Permitted \\ Originally published in: \\ Aquatic Sciences 68(1), https://doi.org/10.1007/s00027-005-0811-4
}




\title{
Research Article
}

\section{Influence of hydraulic conductivity on communities of microorganisms and invertebrates in porous media: a case study in drinking water slow sand filters}

\author{
Laurie Mauclaire $^{1, *}$, Andreas Schürmann ${ }^{1,3}$ and Florian Mermillod-Blondin ${ }^{2}$ \\ ${ }^{1}$ Institute of Terrestrial Ecology, Swiss Federal Institute of Technology (ETH), Universitätstrasse 16, \\ CH-8092 Zürich, Switzerland \\ ${ }^{2}$ UMR-CNRS 5023, LEHF, Lyon I University, 6 rue Dubois, F-69622 Villeurbanne, France \\ ${ }^{3}$ Present address: Zürich Cantonal Laboratory, Pesticide Analysis, Fehrenstrasse 15, CH-8030 Zürich
}

Received: 3 May 2005; revised manuscript accepted: 20 August 2005

\begin{abstract}
The impact of reduced hydraulic conductivity on the abundance and diversity of microorganisms and invertebrates was examined in an artificial ecosystem consisting of a slow sand-filter. Sand-filters processed pre-treated lake water under high flow rates and acted as small ecosystems inhabited by a complex community. The first trophic level consisting of microorganisms serves as a food source for a dense community of protists, micro- and macro-invertebrates. The reduction of hy-
\end{abstract}

draulic conductivity due to the development of larger bacterial and fungal biomass induced a shift of the microbial community towards anaerobiosis that may increase clogging by carbonate precipitation. The presence of more bacterial prey seems to favour the development of higher trophic levels. Predation and bioturbation by eukaryotes were not able to counteract the reduction of hydraulic conductivity due to prokaryotic clogging.

Key words. Biofilm; carbonate; predation; clogging; fatty acid; bioturbation.

\section{Introduction}

Little is known about how complex biological communities of interstitial habitats affect the development of their physical environment. According to the general theory of ecological succession (Engstrom et al., 2000), this system should become more productive with age and the biomass in the sediment should increase with time, leading to bioclogging. By taking advantage of an anthropic system, we observed that the evolution of an infiltrating sedimentary system toward clogging is unpredictable

* Corresponding author mailing address: Laboratory of Geomicrobiology, Geological Institute, ETH Zürich, Universitätstrasse 16, CH-8092 Zürich, Tel.: +41 44632 87 38; fax: +41 4463210 30; e-mail: laurie.mauclaire@erdw.ethz.ch Published Online First: February 20, 2006 based on physical and chemical parameters. Surprisingly, "identical" systems have a completely different clogging behavior due to different development rates in the bacterial exopolymeric substances (Mauclaire et al., 2004).

In the present study, we determined how eukaryotic and prokaryotic communities responded to the clogging process, and attempt to identify factors driving the system progression towards clogging. Sand filters represent specific habitats for micro-, meio- and macro-organisms (Adam et al., 1998; Aeppli 1990; Moll et al., 1999) and we expected that the biological compartment of the artificial infiltrating porous media is highly adapted to its environmental conditions. As microbial development may be controlled by both bottom-up (nutrient resources) and top-down (bioturbation, predation) factors, the aim of this study was to elucidate the relationships between the physical functioning of the system, the microbial 
compartment, and the meio- and macrofauna. Considering that the clogging process would control the nutrient resources of the system (bottom-up control), we hypothesized that an increase in clogging of porous media would lead to a general development of system productivity by increasing abundance, activity, and diversity of the prokaryotic and eukaryotic community.

\section{Materials and methods}

\section{Slow sand filters}

At the water plant Zurich-Lengg, raw water is collected from Lake Zurich (Switzerland) at a depth of $30 \mathrm{~m}$ (more than $20 \mathrm{~m}$ below the thermocline). Primary ozonation is used for disinfection prior to a coarse cleaning by rapid filters. Secondary ozonation and active carbon filtration are conducted before the mechanical and biological superfine cleaning with slow sand filters. These filters $\left(1120 \mathrm{~m}^{2}\right.$ each) are isolated systems with their floors constructed on special bricks for drainage. The sediment tanks consist of four layers of sediment with increasing grain size from the top to the bottom: 85 to $50 \mathrm{~cm}$ of fine sand (diameter $0.2-2 \mathrm{~mm}$ ), $5 \mathrm{~cm}$ of coarse sand (diameter $4-8 \mathrm{~mm}$ ), $5 \mathrm{~cm}$ of fine gravel (diameter $8-15 \mathrm{~mm}$ ), and $5 \mathrm{~cm}$ gravel (diameter $15-30 \mathrm{~mm}$ ). The thickness of the fine sand layers varies according to number of cleaning cycles (removal of the top $5 \mathrm{~cm}$ ). The sand originated from Lake Obersee and was extracted by the sand washing plant Kibag. All filters are operated indoors in the dark at 4 to $8{ }^{\circ} \mathrm{C}$.

Newly constructed filters (clean sand) exhibit an initial hydraulic conductivity of approximately $4-7 \mathrm{~m} \mathrm{~h}^{-1}$. During the following years, the hydraulic conductivity decreases gradually to $0.5 \mathrm{~m} \mathrm{~h}^{-1}$, indicating the increasing clogging of the system. At this point, the filters must be cleaned by removing the top $5 \mathrm{~cm}$ of sand to raise the hydraulic conductivity by $1-2 \mathrm{~m} \mathrm{~h}^{-1}$.

\section{Sampling procedure}

To study the influence of reduced hydraulic conductivity on the biotic system, filters were grouped by the degree of clogging (high and low, Fig. 1). When sampled, highly clogged $(\mathrm{C}+)$ and less clogged (C-) filters had an average hydraulic conductivity of $0.5 \mathrm{~m} \mathrm{~h}^{-1}$ and $1.2 \mathrm{~m} \mathrm{~h}^{-1}$, respectively. For each filter type (C+ and $\mathrm{C}-$ ), three filters were selected. The investigated filters were not subject to maintenance for at least 19 mo, a sufficient time to allow the equilibration of the system.

Samples were collected on three dates: 2 November 2000, 20 March 2001 and 17 May 2001. The last two sampling dates were before and after lake stratification. Saturated hydraulic conductivity of the entire filter was estimated by measuring the pressure head as the difference in water level between the inlet and outlet of each

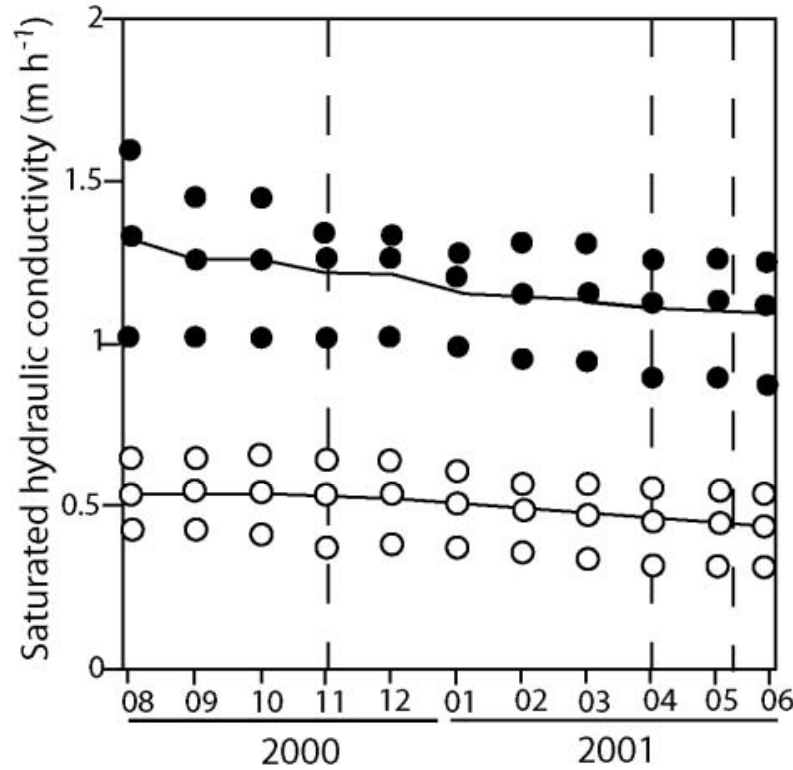

Figure 1. Average saturated hydraulic conductivity of the two sand filter types with sampling dates indicated by the dashed lines. The dots indicate the measurements obtained for each individual filters (triplicates). The black lines and dots correspond to the $\mathrm{C}+$ filters, the grey line and white dots to the $\mathrm{C}$ - filters.

filter at a constant flux rate of $500 \mathrm{~m}^{3} \mathrm{~h}^{-1}$. Samples of sand for microbiological analysis were taken from each filter at 3 points spaced approximately $1 \mathrm{~m}$ apart, forming an equilateral triangle. The triplicate samples of each filter were pooled for subsequent analyses. Sand was collected by coring with a Plexiglas tube (diameter $50 \mathrm{~mm}$ ). The cores were sectioned, and two parts $(0-5 \mathrm{~cm}$ and $15-$ $20 \mathrm{~cm}$ ) were preserved in an icebox for later analysis. The top layer $(0-5 \mathrm{~cm})$ corresponded to the sand removed when slow sand filters are cleaned. Samples of fauna were taken at $100 \mathrm{~cm}$ and $20 \mathrm{~cm}$ depth at one point from each filter using a Bou-Rouch pump (Bou and Rouch, 1967).

\section{SEM observations}

Electron-microscope studies were conducted on a Zeiss Leo 1530 scanning electron microscope (SEM). The sand samples were fixed with $4 \%$ glutaraldehyde for $4{ }^{\circ} \mathrm{C}$. The fixed samples were washed twice in distilled water and dehydrated in ethanol $(50 \%, 80 \%, 98 \%, 3 \mathrm{~min}$ $\times 3$ times each; absolute ethanol $10 \mathrm{~min} \times 3$ times) and critical-point dried in liquid $\mathrm{CO}_{2}$. The samples were coated with platinum prior to SEM imaging.

\section{Biological analysis}

Lipids were extracted as described previously (Mauclaire et al., 2003). The fatty acids were methylated and the fatty acid methyl esters separated by gas chromatography (Hewlett Packard HP 5890 series II equipped with a HP 
Ultra 2 capillary column and a Flame Ionization Detector). Fatty acids with chain lengths of $\mathrm{C} 3$ to $\mathrm{C} 20$ were identified by the MIDI microbial identification system (MIDI, Inc. version 4.0) using TBSA40 and Eukary peak libraries. The fatty acids were grouped as indicated on Table 1. The total amount of PLFAs was converted to cell estimates assuming that, on average, bacteria contain 1 pmol of PLFA within $2 \times 10^{4}$ cells (Green and Scow, 2000).

Meio- and macrofauna were collected from $2 \mathrm{~L}$ of pumped interstitial water filtered through a $180-\mu \mathrm{m}$ mesh net. The fauna was preserved with formaldehyde (4\% final concentration) and extracted under a stereomicroscope.

\section{Data analysis and statistical methods}

The impact of clogging intensity was tested using 3 wayanalysis of variance (ANOVA) with clogging status, date and depths as main effects. When necessary, data were ln-transformed to homogenize variances. The 3-way ANOVAs were performed using Statistica 5 TM (Statsoft, Tulsa, Oklahoma).

\section{Results}

Results from fatty acid concentrations of the different biological groups (Fig. 2), fatty acids of anaerobes (Fig. 3), invertebrate species richness (Fig. 4), and SEM observations (Fig. 5) showed that filters were inhabited by a complex community of micro- and macro-organisms. The microbial community was composed mainly of bacteria (Fig. 2), as indicated by a relatively high abundance of branched fatty acids (used as bacterial markers, Table 1). The presence of dissolved oxygen in interstitial water was indicated by chemical measurements, and both aerobic and anaerobic bacterial markers were detected in all the filters. This result indicates the presence of anaerobic micro-niches within the pore spaces. The prokaryotic community was dominated by Gram-negative bacteria as shown by the high relative abundance of short chain monounsaturated PLFA (Fig. 2). Vertical gradients of PLFA concentrations varied significantly according to the clogging stage of the filter (Table 2). Higher PLFA contents were recorded in the surface of the C+ filters (Fig. 2). Based on published conversion factors, we calculated that the top layer contained $8.7 \times 10^{7}$ bacterial cells $\mathrm{g} \mathrm{sed}^{-1}$ and $6.4 \times 10^{8}$ bacterial cells $\mathrm{g} \mathrm{sed}^{-1}$ for $\mathrm{C}-$ and $\mathrm{C}+$, respectively. The SEM pictures (Fig. 5) confirmed the presence of an abundant microbial community. In C+ filters (Figs. $5,4 a, e, 6 a, 8 b)$, most of the bacteria were embedded in a thick EPS matrix, whereas the EPS matrix was less dense in C- filters (Figs. 5, 1b, 3b). Furthermore, while small carbonate precipitates were detected in the $\mathrm{C}$-filters (Figs. $5,3 \mathrm{c}, 5 \mathrm{c})$, carbonate cementation between the sand grains
Table 1. Biomarker groups of PLFA. PLFA nomenclature is in the form $\mathrm{A}: \mathrm{B} \omega \mathrm{C}$, where $\mathrm{A}$ designates the total number of carbons, $\mathrm{B}$ the number of double bounds and $\mathrm{C}$ the distance of the closest unsaturation from the aliphatic end of the molecule. The prefixes " $\mathrm{i}$ " and " $\mathrm{a}$ " refer to iso- and anteiso-methyl branching, and mid-chain methyl branches are designated by "Me" preceded by the position of the branch from the acid end. The cyclopropyl ring is indicated as "cy".

\begin{tabular}{|c|c|}
\hline $\begin{array}{l}\text { Gram-positive } \\
\text { bacteria }\end{array}$ & $\begin{array}{l}\text { Terminally branched saturated (mainly i14:0, } \\
\text { i15:0, a15:0, i16:0, i17:0, i18:0, i19:0, a19:0, } \\
\text { i21:0) }\end{array}$ \\
\hline $\begin{array}{l}\text { Gram-negative } \\
\text { bacteria }\end{array}$ & 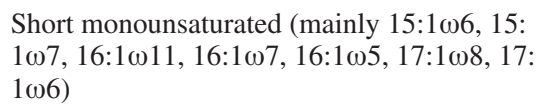 \\
\hline Anaerobes & 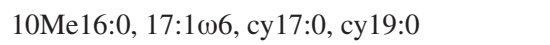 \\
\hline Actinomycetes & i14:1, i15:1,i16:1, i17:1, a17:1, i18:1, i19:1 \\
\hline Microeukaryota & 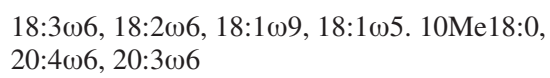 \\
\hline Fungi & $18: 3 \omega 6,18: 2 \omega 6,18: 1 \omega 9,18: 1 \omega 5.10 \mathrm{Me} 18: 0$ \\
\hline Protists & $20: 4 \omega 6,20: 3 \omega 6$ \\
\hline
\end{tabular}

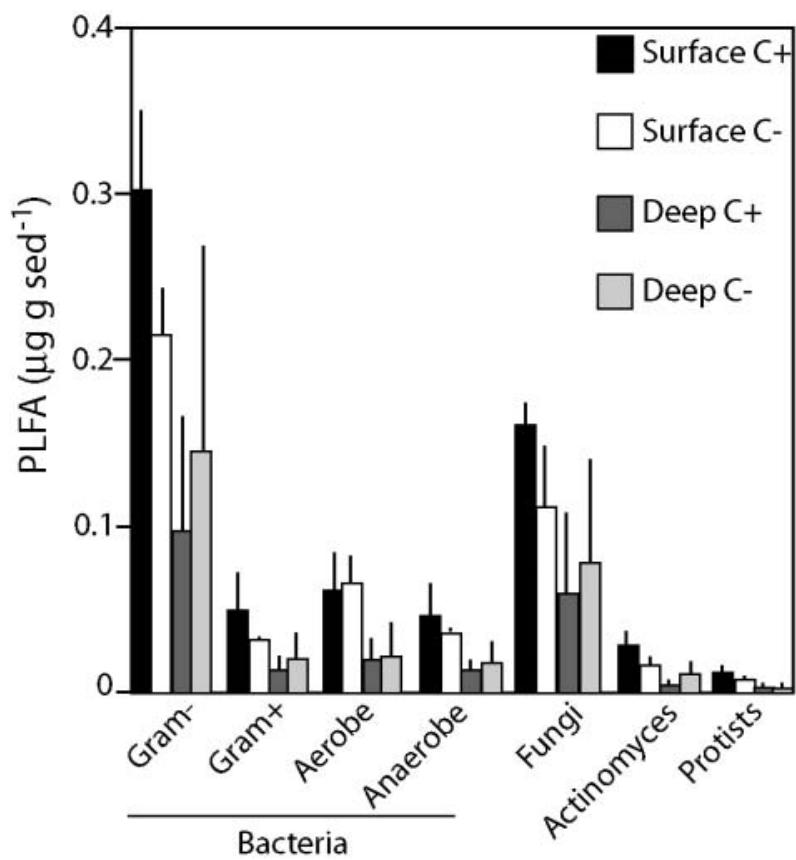

Figure 2. Spatial variation of the biomarker groups in the top (0$5 \mathrm{~cm}$ depth) and deep layers (15-20 cm depth) of the C+ and C- filters as averages with standard deviations for the three sampling dates $(\mathrm{n}=9)$.

(Figs. 5, 2a) and calcification of micro-organisms (Figs. $5,4 \mathrm{c}$ ) were observed in the $\mathrm{C}+$ filters.

Faunal abundance showed similar spatial distribution to microbial abundance. In C+ filters, faunal abundance significantly decreased with depth, whereas in $\mathrm{C}$ - filters no significant vertical gradient was observed (Fig. 4 and Table 3). Although the bottom part of both filters contained similar densities of organisms, invertebrate abun- 
dance was significantly higher in $\mathrm{C}+$ filters $\left(331\right.$ ind $\left.^{-1}\right)$ compared to $\mathrm{C}-$ filters $\left(133\right.$ ind $\left.\mathrm{l}^{-1}\right)$. Nematodes and oligochaetes always represented more than $50 \%$ of the overall faunal abundance. The majority of the biomass

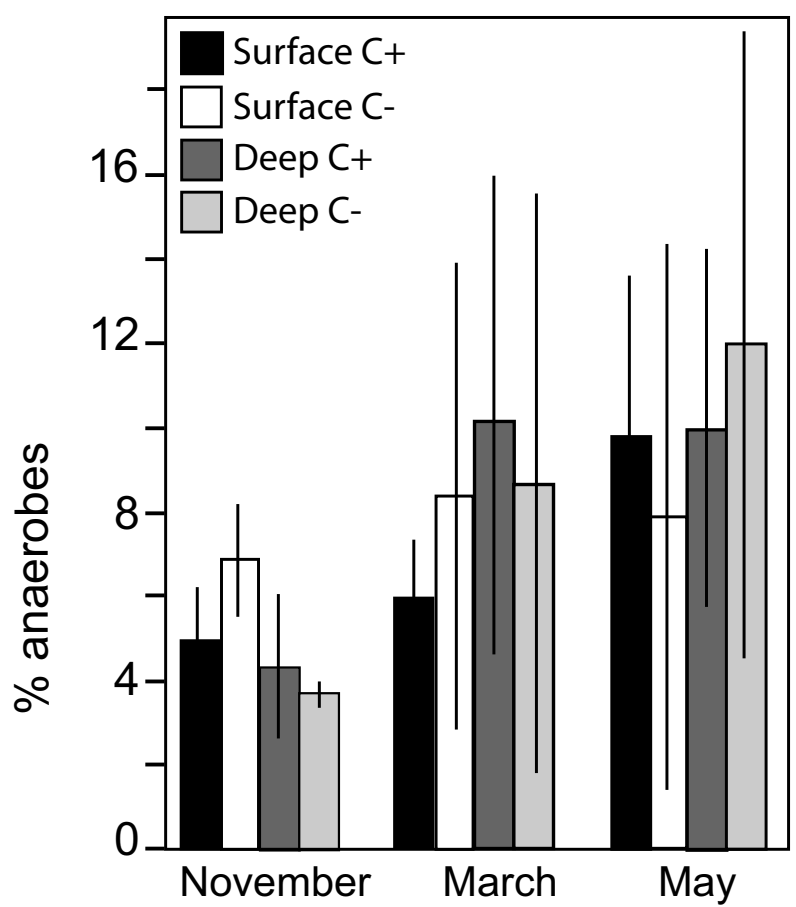

Figure 3. Spatial and temporal variation of the anaerobic biomarkers relative to the total fatty acid concentrations in the top $(0-5 \mathrm{~cm}$ depth) and deep $(15-20 \mathrm{~cm})$ layers of the $\mathrm{C}+$ and $\mathrm{C}$ - filters as average $(n=3)$.

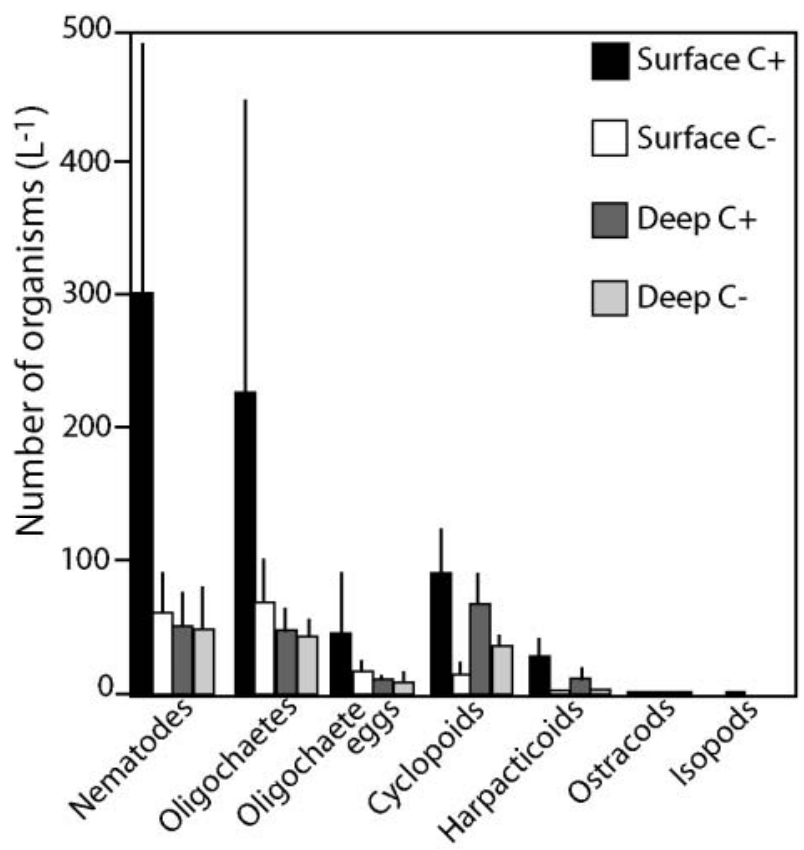

Figure 4. Spatial variation of the fauna in the surface $(20 \mathrm{~cm})$ and deep $(100 \mathrm{~cm})$ layers of the $\mathrm{C}+$ and $\mathrm{C}$ - filters as averages with standard deviations for the three sampling dates $(n=9)$. within the system consisted of oligochaetes, which, like other taxa were more abundant in the top part of the $\mathrm{C}+$ filters (Fig. 4). Micro-crustacea (cyclopoids, harpacticoids and ostracods) represented $1-45 \%$ of the fauna. The only macro-crustacean found, Asellus aquaticus, was rare and only present in the top layer of $\mathrm{C}$ - filters.

The 3-way ANOVAs indicated a significant increase in microbial and faunal abundance and diversity with time, especially at the surface of the C+ filters (effect "date", Table 2). The relative importance of anaerobes compared to the total amount of PLFA increased from about $4 \%$ in November to $10 \%$ in May, indicating the development of anaerobic microniches in sediments (Fig. 3 ). Furthermore, anaerobes changed over time according to the clogging intensity (effect of "date $\times$ clogging", Table 2). In the C- filters, the percentage of anaerobes remained stable at the surface of the filters, whereas it regularly increased deeper. In C+ filters, similar development was observed between November and March, although on the last sampling date (May), the prevalence of anaerobes increased at the surface of sediment (Fig. 3). Similarly, the vertical gradients of Gram-positive and Gram-negative bacteria, actinomycetes, microeukaryotes, fungi, and protists were significantly different according to the clogging intensity (effect of "depth $\times$ clogging", Table 2). PLFA concentrations were higher in the top layers of $\mathrm{C}+$ than in $\mathrm{C}$ - filters, whereas no significant differences in PLFA contents were measured between $\mathrm{C}+$ and $\mathrm{C}-$ filters in the deep layer. For the invertebrates, both nematode and micro-crustacean abundances were significantly higher in clogged filters (effect "clogging", Table 2).

\section{Discussion}

Biodiversity of the artificial infiltrating porous media The community structure of micro-organisms inhabiting the slow sand filters supports the results of other studies showing that Gram-negative bacteria are the most abundant microbial group in drinking water systems (Keinänen et al., 2003; Lahti, 1993; Payment et al., 1988; Smith et al., 2000). Eukaryotic markers did not represent the major part of the microbial community in terms of biomass, although they were detected in all the filters. Like Moll et al. (1999), we observed an increasing prevalence of Gram-negative bacteria and microeukaryotes in our filters operating at low temperatures (between 4 to $8^{\circ} \mathrm{C}$ ). The identification of 22:6w3, a biomarker of psychrophilic bacteria (Bowman et al., 2003), in nearly all the samples indicated that the microbial population living in the filters is well adapted to this particular environment. Low temperature also affects the development of the invertebrates (Adam et al., 1998). Furthermore, the filters (indoor tanks) are completely isolated from natural 
Table 2. ANOVA results table with date, clogging status and depth as tested effects. * data log transformed, df degrees of freedom.

\begin{tabular}{|c|c|c|c|c|c|c|c|c|}
\hline & & date & $\begin{array}{l}\text { clog. } \\
\text { status }\end{array}$ & depth & $\begin{array}{l}\text { date } \mathrm{x} \\
\text { clog. }\end{array}$ & $\begin{array}{l}\text { date } x \\
\text { depth }\end{array}$ & $\begin{array}{l}\text { clog. } x \\
\text { depth }\end{array}$ & $\begin{array}{l}\text { date } x \\
\text { depth } x \\
\text { clog. }\end{array}$ \\
\hline df & & 2 & 1 & 1 & 2 & 2 & 1 & 2 \\
\hline \multicolumn{9}{|l|}{ PLFA } \\
\hline Abundance * & $\begin{array}{l}F \\
p\end{array}$ & $\begin{array}{l}12.17 \\
0.000 \\
\end{array}$ & $\begin{array}{l}2 \\
.17\end{array}$ & $\begin{array}{l}71.66 \\
0.000 \\
\end{array}$ & $\begin{array}{l}2.71 \\
0.09\end{array}$ & $\begin{array}{l}8.06 \\
0.002 \\
\end{array}$ & $\begin{array}{l}10.59 \\
0.003 \\
\end{array}$ & $\begin{array}{l}0.05 \\
0.96\end{array}$ \\
\hline Number of peak & $\begin{array}{l}F \\
p\end{array}$ & $\begin{array}{l}2.99 \\
0.07\end{array}$ & $\begin{array}{l}0.83 \\
0.37\end{array}$ & $\begin{array}{l}13.05 \\
0.001 \\
\end{array}$ & $\begin{array}{l}2.15 \\
0.14\end{array}$ & $\begin{array}{l}3.7 \\
\underline{0.04} \\
\end{array}$ & $\begin{array}{l}0.19 \\
0.67\end{array}$ & $\begin{array}{l}2.96 \\
0.07\end{array}$ \\
\hline \multicolumn{9}{|c|}{ Biomarker group of PLFA } \\
\hline Gram-positive * & $\begin{array}{l}F \\
p\end{array}$ & $\begin{array}{l}4.62 \\
\underline{0.02} \\
\end{array}$ & $\begin{array}{l}1.85 \\
0.19\end{array}$ & $\begin{array}{l}34.3 \\
\underline{0.000}\end{array}$ & $\begin{array}{l}2.97 \\
0.07\end{array}$ & $\begin{array}{r}4.73 \\
0.02 \\
\end{array}$ & $\begin{array}{l}6.42 \\
\underline{0.018} \\
\end{array}$ & $\begin{array}{l}0.7 \\
0.51\end{array}$ \\
\hline Gram-negative & $\begin{array}{l}F \\
p\end{array}$ & $\begin{array}{l}15.1 \\
\underline{0.000}\end{array}$ & $\begin{array}{l}0.99 \\
0.33\end{array}$ & $\begin{array}{l}71.5 \\
\underline{0.000}\end{array}$ & $\begin{array}{l}2.07 \\
0.15\end{array}$ & $\begin{array}{l}6.86 \\
\underline{0.004} \\
\end{array}$ & $\begin{array}{l}7.37 \\
\underline{0.012}\end{array}$ & $\begin{array}{l}0.12 \\
0.88\end{array}$ \\
\hline Anaerobes & $\begin{array}{l}F \\
p\end{array}$ & $\begin{array}{l}0.05 \\
0.95\end{array}$ & $\begin{array}{l}0.7 \\
0.41\end{array}$ & $\begin{array}{l}30.1 \\
\underline{0.000}\end{array}$ & $\begin{array}{r}3.94 \\
0.03 \\
\end{array}$ & $\begin{array}{l}8.13 \\
0.002 \\
\end{array}$ & $\begin{array}{l}3.29 \\
0.08\end{array}$ & $\begin{array}{l}1.4 \\
0.27\end{array}$ \\
\hline Actinomycetes * & $\begin{array}{l}F \\
p\end{array}$ & $\begin{array}{l}0.01 \\
0.99\end{array}$ & $\begin{array}{l}0.26 \\
0.61\end{array}$ & $\begin{array}{l}19.2 \\
\underline{0.000}\end{array}$ & $\begin{array}{l}2.53 \\
0.10\end{array}$ & $\begin{array}{l}5.82 \\
\underline{0.009} \\
\end{array}$ & $\begin{array}{l}9.28 \\
\underline{0.006}\end{array}$ & $\begin{array}{l}0.02 \\
0.978\end{array}$ \\
\hline Microeukaryota & $\begin{array}{l}F \\
p\end{array}$ & $\begin{array}{l}9.24 \\
0.001\end{array}$ & $\begin{array}{l}1.51 \\
0.23\end{array}$ & $\begin{array}{l}25.1 \\
\underline{0.000}\end{array}$ & $\begin{array}{l}0.48 \\
0.62\end{array}$ & $\begin{array}{l}2.24 \\
0.13\end{array}$ & $\begin{array}{l}5.4 \\
\underline{0.03} \\
\end{array}$ & $\begin{array}{l}0.54 \\
0.59\end{array}$ \\
\hline Fungi & $\begin{array}{l}F \\
p\end{array}$ & $\begin{array}{l}8.96 \\
0.001 \\
\end{array}$ & $\begin{array}{l}1.1 \\
0.30\end{array}$ & $\begin{array}{l}21.2 \\
\underline{0.000}\end{array}$ & $\begin{array}{l}0.48 \\
0.63\end{array}$ & $\begin{array}{l}2.18 \\
0.13\end{array}$ & $\begin{array}{r}4.98 \\
0.03 \\
\end{array}$ & $\begin{array}{l}0.45 \\
0.64\end{array}$ \\
\hline Protists & $\begin{array}{l}F \\
p\end{array}$ & $\begin{array}{l}1.79 \\
0.19\end{array}$ & $\begin{array}{l}3.47 \\
0.07\end{array}$ & $\begin{array}{l}69.03 \\
\underline{0.000} \\
\end{array}$ & $\begin{array}{l}2.61 \\
0.09\end{array}$ & $\begin{array}{l}4.9 \\
\underline{0.02} \\
\end{array}$ & $\begin{array}{l}5.45 \\
\underline{0.03} \\
\end{array}$ & $\begin{array}{l}1.13 \\
0.34\end{array}$ \\
\hline \multicolumn{9}{|l|}{ Invertebrates } \\
\hline Number of taxa ${ }^{*}$ & $\begin{array}{l}F \\
p\end{array}$ & $\begin{array}{l}102.8 \\
0.000 \\
\end{array}$ & $\begin{array}{l}2.2 \\
0.15\end{array}$ & $\begin{array}{l}1.5 \\
0.24\end{array}$ & $\begin{array}{l}2.4 \\
0.11\end{array}$ & $\begin{array}{l}0.6 \\
0.56\end{array}$ & $\begin{array}{l}0.7 \\
0.41\end{array}$ & $\begin{array}{l}0.3 \\
0.71\end{array}$ \\
\hline Oligochaetes * & $\begin{array}{l}F \\
p\end{array}$ & $\begin{array}{l}1.37 \\
0.27\end{array}$ & $\begin{array}{l}2.04 \\
0.17\end{array}$ & $\begin{array}{l}5.07 \\
\underline{0.03} \\
\end{array}$ & $\begin{array}{l}0.14 \\
0.87\end{array}$ & $\begin{array}{l}0.93 \\
0.41\end{array}$ & $\begin{array}{l}0.15 \\
0.71\end{array}$ & $\begin{array}{l}0.42 \\
0.66\end{array}$ \\
\hline Nematodes * & $\begin{array}{l}F \\
p\end{array}$ & $\begin{array}{l}1.63 \\
0.22\end{array}$ & $\begin{array}{r}4.46 \\
0.04 \\
\end{array}$ & $\begin{array}{r}4.84 \\
0.04 \\
\end{array}$ & $\begin{array}{l}0.26 \\
0.77\end{array}$ & $\begin{array}{l}0.38 \\
0.69\end{array}$ & $\begin{array}{l}1.14 \\
0.29\end{array}$ & $\begin{array}{l}0.34 \\
0.72\end{array}$ \\
\hline Microcrustaceans* & $\begin{array}{l}F \\
p\end{array}$ & $\begin{array}{l}3.15 \\
0.06\end{array}$ & $\begin{array}{l}12.51 \\
0.002\end{array}$ & $\begin{array}{l}0.030 \\
0.87\end{array}$ & $\begin{array}{l}0.32 \\
0.73\end{array}$ & $\begin{array}{l}0.30 \\
0.74\end{array}$ & $\begin{array}{l}0.78 \\
0.39\end{array}$ & $\begin{array}{l}0.45 \\
0.64\end{array}$ \\
\hline
\end{tabular}

sediment ecosystems and flying adult insects. This particular filter design may explain the relatively low abundance of invertebrates and the absence of insect larvae in these filters compared to the fauna communities in warmer outdoor slow sand filters (Jellison et al., 2000, Wotton and Hirabayashi, 1999).

The studied filters are artificial systems characterized by a peculiar fauna that differed from that observed in the raw water, which contained mainly micro-crustaceans (Aeppli, 1990; Smart and Harper, 1999). Because of the ozone treatment, direct colonization is unlikely and the animals probably descended from individuals introduced during the sand filling. However, the ozone pretreatments do not impair development of organisms within the filters (Urfer and Huck, 1999; Foncesca et al., 2001; Moll et al.,
1998). Although SEM revealed the presence of numerous diatom skeletons (Figs. 4, 7a) and a structure looking like an extremely small Spirulina (Figs. 4, 4d), there was no evidence that the living microbial community established in the filters was derived from the lake. The cleaning procedure of the raw water (ozonation and rapid carbon filtration) appears to be highly efficient since biomarkers of diatoms, microalgae and green algae, which are abundant in the lake of Zurich, were not detected. The absence of long-chain polyunsaturated fatty acids also confirms the absence of phytoplankton in the filters. This result is consistent since the filters are maintained in the dark, preventing phototrophic activity. However, it is interesting to note that there is no direct relation between the phytoplankton bloom observed in the lake between the 

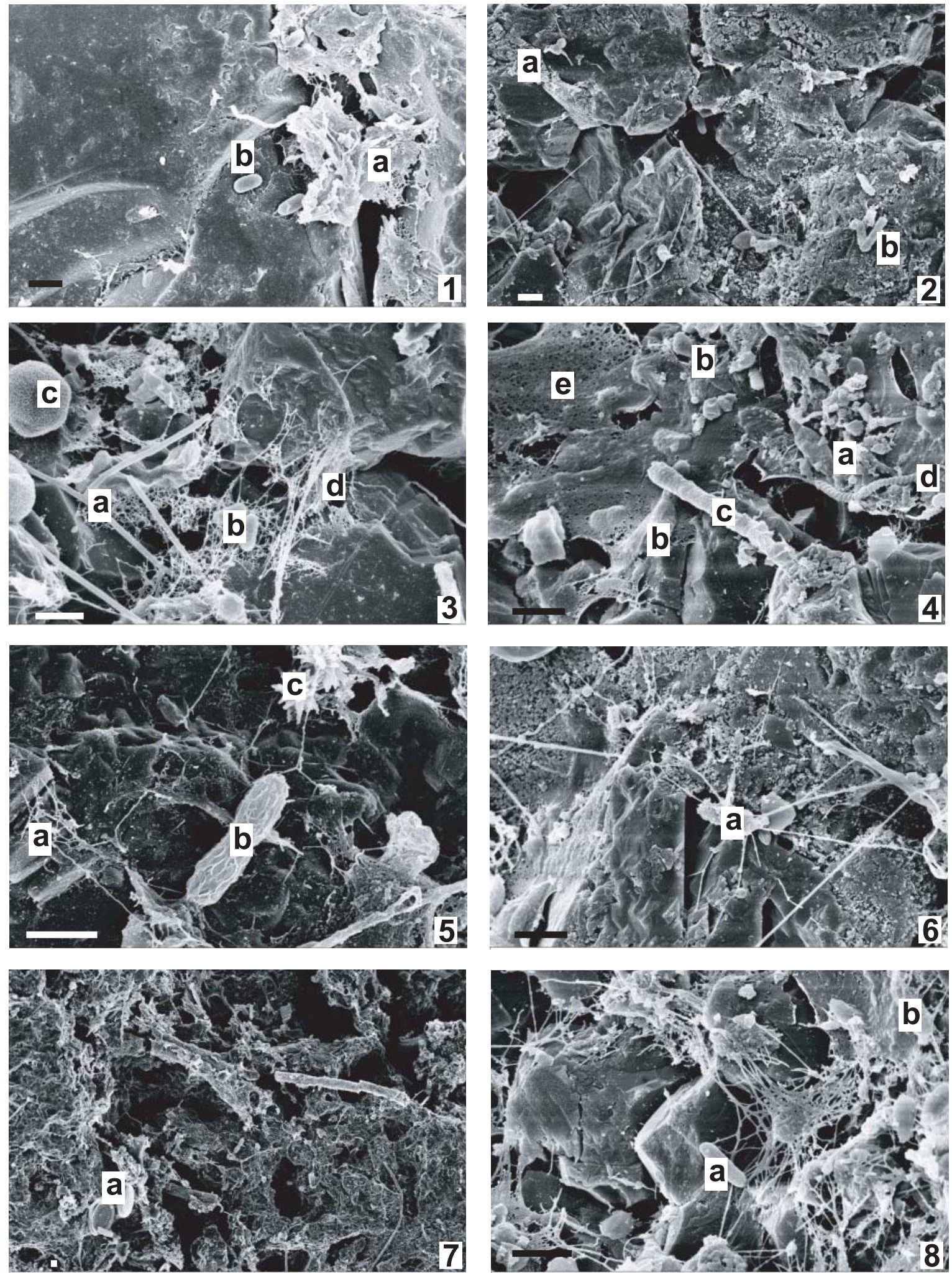

Figure 5. Scanning electron micrographs of sediment from the slow sand filters (top layer): C- filters (odd numbers) and C+ filters (even numbers). Picture 1a- EPS filling the space between sand grains, 1b- bacteria, 2a- carbonate precipitation cementing the space between sand grain, 2b- bacteria, 3a- fungal hyphae, 3b- bacteria, 3c- calcite precipitation, 3d- fine EPS deposit, 4a- small bacterial cocci embedded in EPS, 4b- bacteria rod embedded in EPS, 4c- calcified microorganisms, 4d- "nano spirulina", 5a- fine EPS film, 5b- bacteria covered by fine EPS, $5 c$ - carbonate precipitate, $6 \mathrm{a}$ - bacteria covered by a dense EPS accumulation, 7a- diatom skeleton, 8a- bacteria free of EPS, $8 \mathrm{~b}$ - bacteria embedded in EPS. 
March and May sampling and the microbial community established in the filters.

\section{Clogging processes and biological responses}

As hypothesised, the increase of clogging provoked significant changes in the abundance and diversity of prokaryotes and eukaryotes, and appeared to stimulate microbial activity. Several studies demonstrated that microbial growth is related to hydrodynamics in porous media (Molz et al., 1986; Murphy et al., 1997) and predicted that a reduction of the hydraulic conductivity prolonged the contact between flowing water and biofilms, stimulating the incorporation of the nutrients transported by water in the top layer of clogged systems. Such nutrient incorporation thus produced a positive feedback to the clogging process by stimulating the bacterial development in the surface layer of sediments. Furthermore, the bacterial stimulation may also increase the clogging process by facilitating the carbonate precipitation. As there was more biofilm in the clogged filter, it is expected that anaerobes would develop better in the $\mathrm{C}+$ filters than in $\mathrm{C}$ - filters. Although the smell of $\mathrm{H}_{2} \mathrm{~S}$ was never detected during the sampling, the presence of 10Me16:0, a biomarker of Desulfovibrio species (Edlund et al., 1985), indicated that part of the microbial community reduced sulfate. The possible shift of the microbial community towards sulphate-reducing activity has implications for carbonate precipitation. Although aerobic oxidation favours the carbonate dissolution by releasing carbon dioxide, anaerobic oxidation by sulphate-reducing bacteria at pH 8 favours carbonate precipitation by production of bicarbonate. This hypothesis is confirmed by SEM observation of the sand samples (Fig. 5). Previous observations demonstrated that carbonate precipitate occupied a similar pore volume to the exopolymeric substances in our filters (Mauclaire et al., 2004). Furthermore, the presence of hydrogen sulfide may provoke the precipitation of iron and manganese. This phenomenon, reported in similar filtration systems (Vandenabeele et al., 1992), was not observed in the Zurich-Lengg filters.

The source of bioclogging in porous media is usually biofilm that grows on the surface of grains and is smaller than a millimeter. The biofilm volume estimates (Mauclaire et al., 2004) were confirmed by SEM observations (Fig. 5): the EPS were more abundant and thicker in the $\mathrm{C}+$ than in the $\mathrm{C}-$ filters. Furthermore, fungi and actinomycetes, which grow as filaments, can occupy many pores with dimensions approaching the centimetre scale (Dupin and McCarty, 1999). Presence of fungal hyphae was confirmed by SEM observations (Figs. 5, 3a). In the $\mathrm{C}+$ filters, fungi and actinomycetes biomarkers were more abundant than in $\mathrm{C}$ - filters, further favouring bioclogging.

Protists in porous media have been used to account both for hydraulic conductivity increases and decreases.
In column experiments, the addition of heterotrophic nanoflagellates or amoebae merely delayed the occurrence of clogging (DeLeo and Baveye, 1997; Weber-Shirk and Dick, 1999; Mattison et al., 2002), probably by grazing on attached bacteria. However, in our study, predator abundances were significantly higher at the surface of $\mathrm{C}+$ filters. This finding demonstrates that predation was not sufficient to reduce bacterial growth. In complex environments such as slow sand filters, the increase of predation stimulated microbial growth, which in turn reduced hydraulic conductivity. Furthermore, grazing might weaken adhesion of bacterial colonies (Honda and Matsumota, 1983; Cullimore and Mansuy, 1987). The resulting biofilm detachment and subsequent filtration of clumps at strategic points such as pore constriction could explain the observed accelerated clogging (Taylor and Jaffé, 1990).

As with predation, invertebrate activities have been related to increases and decreases in hydraulic conductivity (Eder, 1982; Torreiter et al., 1994). Macroinvertebrates, such as nematodes or oligochaetes, generate biogenic structures, bioirrigation and various types of sediment reworking. Collectively, these processes, termed bioturbation, take place at the inhabited part of the benthic habitat (Gerino et al., 1999) and can favour water infiltration by producing tubes and galleries in the clogged layers of sand filters. Although in our study, the sampling point of microorganisms and invertebrates only overlapped at $20 \mathrm{~cm}$ depth and densities of invertebrates were probably too low to significantly affect hydraulic conductivity, bioturbator abundance was positively correlated with reduction of hydraulic conductivity. This correlation was probably the result of a trophic interaction between micro- and macro-fauna; as invertebrates living in sediments mostly feed on biofilm associated with particles (see review in Boulton, 2000), the stimulating effect of clogging on the density of micro-organisms may have also favoured the development of macroinvertebrates. Furthermore, invertebrates may have stimulated the microbial growth by modifying the chemical environment of the interstitial habitat, keeping the microbial communities in a growing state, and excreting nutrients into the system (Yingst and Rhoads, 1980; Aller, 1994; Griebler, 1996; Traunspurger et al., 1997; MermillodBlondin et al., 2004).

\section{Conclusion}

Biological communities inhabiting sand filters comprise organisms from bacteria to invertebrates, that belong to different trophic levels. The study of filters with different clogging intensities demonstrated that the community structure of both prokaryotes and eukaryotes depends on the rate of filtration. The reduction of hydraulic conduc- 
tivity could be interpreted as an early stage of sand diagenesis with accumulation of biomass within the pore space and the development of a complex community of micro- and macro-organisms. Furthermore, the shift of microbial community from aerobic to anaerobic conditions might favor carbonate precipitation and thus the clogging process.

This study suggests approaches to prevent or minimize the clogging of the sand filter and obtain more sustainable management. The microbial activity within the filter was limited by the intense pre-treatment of the infiltrated lake water and the design of the filter. As these physical and chemical limitations did not completely prevent clogging, we speculate that the presence of organisms grazing on biofilm such as protists (Mattison et al., 2002) and invertebrates might help prevent clogging. In the present study, invertebrate density was low and essentially linked to the occurrence of microorganisms. Such low densities were probably not sufficient to modify the clogging status of the filters. We can speculate that the introduction of higher densities (e.g. 10.000 individuals per $\mathrm{m}^{2}$ or more than 1000 individuals per liter) of invertebrates such as tubificid worms could minimize the clogging process due to grazing and bioturbation. Introduction of invertebrates which produce galleries in the sediments (Mermillod-Blondin et al., 2005; Rogaar, 1980) could maintain the hydraulic conductivity of the system. Such biological treatment has, however, never been tested and future research on clogging of sand filter should consider that metazoans could help to maintain the hydrological functioning of filtration systems.

\section{Acknowledgments}

The authors would like to thank Prof. Dr. J. Zeyer head of the Soil Biology group (ETHZ) for initiating this work, Dr. M. Mueller of the Institute of Applied Physics (ETHZ) for the SEM study, and K. Sutter \& R. Stettler from Zurich Water Supply for their warm welcome and help. We are grateful to Andrew Boulton and two anonymous reviewers for their very insightful comments.

\section{References}

Adam, K, R. G. M. Heath and M. C. Steynberg, 1998. Invertebrates as biomonitors of sand-filter efficiency. Water Science Association 24: 43-48.

Aeppli, J. 1990. Appearance of invertebrates in slow sand filters and reservoirs of the Zurich Switzerland Water Supply. Aqua 39: $48-55$.

Aller, R. C., 1994. Bioturbation and remineralization of sedimentary organic matter: effects of redox oscillation. Chemical Geology 114: $331-345$.

Boulton, A. J., 2000. The functional role of the hyporheos. Verhandlungen der Internationalen Vereinigung für Theorische und Angewardte Limnologie 27: 51-63.
Bou, C. and R. Rouch, 1967. Un nouveau champ de recherches sur la faune aquatique souterraine. Comptes rendus de l'Academie des Sciences de Paris 265: 369-370.

Bowman, J. P., S. A. McCammom, J. A. E. Gibson, L. Robertson and P. D. Nichols, 2003. Prokaryotic metabolic activity and community structure in Antarctic continental shelf sediments. Applied and Environmental Microbiology 69: 2448-2462.

Cullimore, D. R. and N. A. Mansuy, 1987. A screen arc model well to simulate iron bacterial fouling. Journal of Microbiological Methods 7: 225-232.

DeLeo, P. C. and P. Baveye, 1997. Factors affecting protozoan predation of bacterial clogging laboratory aquifer microcosms. Geomicrobiology Journal 14: 127-152.

Dupin, H. J. and P. L. McCarty, 1999. Mesoscale and microscale observations of biological growth in a silicon pore imaging element. Environmental Science and Technology 33: 1230-1236.

Eder, R., 1982. The role of nematodes in sand filtration processes. Stygo News 3: 20-22.

Edlund, A., P. D. Nichols, R. Roffey and D. C. White, 1985. Extractable and lipopolysaccharide fatty-acid and hydroxy acid profiles from Desulfovibrio species. Journal of Lipid Research 26: 982-988.

Engstrom, D. R., S. C. Fritz, J. E. Almendinger and S. Juggins, 2000. Chemical and biological trends during lake evolution in recently deglaciated terrain. Nature 408: 161-166.

Fonseca, C. A., R. A. Summers and M. T. Hernandez, 2001. Comparative measurements of microbial activity in drinking water biofilters. Water Research 16: 3817-3824.

Gerino, M., G. Stora and O. Weber, 1999. Evidence of bioturbation in the Cap-Ferret Canyon in the deep northeastern Atlantic. Deep-Sea Research part II- Topical Studies in Oceanography 46: $2289-2307$.

Green, C. T. and K. M. Scow, 2000. Analysis of phopholipid fatty acids (PLFA) to characterize microbial communities in aquifers. Hydrogeology Journal 8: 126-141.

Griebler, C., 1996. Some applications for the DMSO-reduction method as a new tool to determine the microbial activity in water-saturated sediments. Archiv für Hydrobiologie Supplement 113: 405-410.

Honda, Y. and J. Matsumoto, 1983. The effect of temperature on the growth of microbial film in a model trickling filter. Water Research 17: 375-382.

Keinänen, M. M., P. J. Martikainen, L. K. Korhonen and M. Suutari, 2003. Microbial community structure in biofilms and water of a drinking water distribution system determined by lipid biomarkers. Water Science and Technology 47: 143-147.

Jellison, K. L., R. I. Dick and M. L. Weber-Schirk, 2000. Enhanced ripening of slow sand filters. Journal of Environmental Engineering - ASCE 126: 1153-1157.

Lahti, K., 1993. Microbial quality of drinking water in some Finnish distribution systems. Water Science and Technology 2: 151-154.

Mattison, R. G., H. Taki and S. Harayama, 2002. The bacterivorous soil flagellate Heteromita globosa reduces bacterial clogging under denitrifying conditions in sand filled aquifer columns. Applied and Environmental Microbiology 68: 4539-4545.

Mauclaire, L., O. Pelz, W.-R. Abraham and J. Zeyer, 2003. Assimilation of toluene carbon along a bacteria-protist food chain determined by ${ }^{13} \mathrm{C}$-enrichment of biomarker fatty acids. Journal of Microbiological Methods 55: 635-649.

Mauclaire, L., A. Schürmann, M. Thullner, S. Gammeter and J. Zeyer, 2004. Sand filtration in water treatment plant: biological parameters responsible for clogging. Journal of Water Supply Research and Technology - Aqua 53: 93-107.

Mermillod-Blondin, F., J. P. Gaudet, M. Gerino, G. Desrosiers, J. Jose and M. Creuzé des Châtelliers, 2004. Relative influence of bioturbation and predation on organic matter processing in river sediments: A microcosm experiment. Freshwater Biology 49: 895-912.

Mermillod-Blondin, F., G. Nogaro, T. Datry, F. Malard and J. Gibert, 2005. Do tubificid worms influence the fate of organic mat- 
ter and pollutants in stormwater sediments? Environmental Pollution 134: 57-69.

Moll, D. M., R. S. Summers and A. Breen, 1998. Microbial characterization of biological filters used for drinking water treatment. Applied and Environmental Microbiology 64: 2755-2759.

Moll, D. M., R. S. Summers, A. C. Foncesca and W. Matheis, 1999. Impact of temperature on drinking water performance and microbial community structure. Environmental Science and Technology 33: 2377-2382.

Molz, F. J., M. A. Widdowson and L. D. Benefield, 1986. Simulation of microbial-growth dynamics coupled to nutrient and oxygentransport in porous-media. Water Resource Research 22: 1207-1216.

Murphy, E. M., T. R. Ginn, A. Chilakapati, C. T. Resch, J. L. Phillips, T. W. Wietsma and C. M. Spadoni, 1997. The influence of physical heterogeneity on microbial degradation and distribution in porous media. Water Resource Research 33: 1087 1103.

Payment, P., F. Gamache and G. Paquette, 1988. Microbial and virological analysis of water from two water filtration plants and their distribution systems. Canadian Journal of Microbiology 34: 1304-1309.

Rogaar, H., 1980, The morphology of burrow structures made by tubificids. Hydrobiologia 71: 107-124.

Smart, A. C. and D. M. Harper, 1999. Life after lakes: the ecology and management of the water distribution network. Hydrobiologia 395/396: 379-386.

Smith, C. A., C. B. Phiefer, S. J. Macnaughton, A. Peacock, R. S. Burkhalter, R. Kirkegaard and D. C. White, 2000. Quantitative lipid biomarker detection of unculturable microbes and chlorine exposure in water distribution system biofilms. Water Research 34: $2683-2688$.

Taylor, S. W. and R. R. Jaffé, 1990. Biofilm growth and related changes in the physical properties of a porous media. 1. Experimental investigations Water Resources Research 26: 2153 2159.

Torreiter, P., P. Pitaksintorn-Watanamahart and D. L. Danielopol, 1994. The activity of oligochaetes in relation to their ecological role in slow filtration columns. In Stanford, J. A. and H. M. Valett, (eds) Second International Conference on Ground Water Ecology. US EPA \& American Water Resources Association, Herndon, Virginia, Atlanta, Georgia, 85-94.

Traunspurger, W., M. Bergtold and W. Goedkoop, 1997. The effects of nematodes on bacterial activity and abundance in a freshwater sediment. Oecologia 112: 118-122.

Urfer, D. and P. M. Huck, 1999. A study of the impacts of periodic ozone residuals on biologically active filters. Ozone Science and Engineering 22: 77-97.

Vandenabeele, J., D. De Beer, R. Gremonpre and W. Werstraete, 1992. Manganese oxidation by microbial consortia from sand filters. Microbial Ecology 24: 91-108.

Weber-Shirk, M. L. and R. I. Dick, 1999. Bacterivory by a chrysophyte in slow sand filters. Water research 33: 631-638.

Wotton, R. S. and K. Hirabayashi, 1999. Midge larvae (Diptera, Chirononmidae) as engineers in slow sand filter beds. Water Research 33: 1509-1515.

Yingst, J. Y. and D. C. Rhoads, 1980. The role of bioturbation in the enhancement of microbial turnover rates in marine sediments. In Tenore, K. R. C. and B. C. Coull (eds), Marine Benthic Dynamics. University of South Carolina Press, Columbia, 407-422.

\section{(15) To access this journal online: \\ (4P) http://www.birkhauser.ch}

